\title{
USELESS ACTIONS AND SENSELESS LAUGHTER: ON MOSCOW CONCEPTUALIST ART AND POLITICS
}

\author{
YELENA KALINSKY
}

\begin{abstract}
Through a series of close readings of an album by Il'ia Kabakov and actions by the groups Collective Actions (Kollektivnye deistviia) and Mukhomor, this article considers the place of laughter in the work of the Moscow Conceptualist circle. Distinguishing between a metaphysically-oriented laughter in the 1970s and a carnivalesque or kynic laughter in the 1980s, the article rejects the easy identification of Moscow Conceptualism's ironic laughter with a social and political critique of the Soviet Union, and instead locates these different strains of Moscow Conceptualist practice in the shifting artistic and political contexts of the last two Soviet decades.

Keywords: Laughter; Il'ia Kabakov; Kollektivnye deistviia; Mukhomor; Moscow Conceptualism
\end{abstract}

Moscow Conceptualism, the late-Soviet art movement, is often said to be characterized by an ironic laughter, which critics trace by a genetic connection to the comic stories of Gogol' and the absurdist poetry of Chlebnikov and Obèriu. This identification of Moscow Conceptualism with irony and satire is buttressed by comparisons with the critical strategies of North American and West European conceptual art, which employed tautology and institutional critique to shed light on the limits of art's prevailing definitions and the vested interests of artistic institutions. Such links with Russian literary satire and Western Conceptualism, while illuminating in certain 
respects, risk casting Moscow Conceptualism as an art of social and political critique, inviting us to read its ironic laughter as a strategy of enlightenment pointed at Soviet ideology. ${ }^{1}$ For although they shared Western Conceptualism's mistrust of the High Modernist art object and claimed Gogol', Chlebnikov, and Charms as forefathers, most Moscow Conceptualist artists at the height of the movement in the 1970s sidestepped a materialist critique of culture in favor of the immaterial. Examined closely, many paradigmatic Moscow Conceptualist works that begin with laughter end up in the realm of metaphysics. But rather than expressing individual spiritual visions as did, for example, the metaphysically-oriented painters in the 1960s and 1970s, or the collective utopian impulses of the Russian avant-garde, Moscow Conceptualism used laughter, among other aesthetic strategies, to gesture towards the presence of metaphysical questions and to create spaces for their collective discursive elaboration.

This essay will explore the echoes of ironic laughter in the activities of conceptual artists in Moscow from the late-1960s through the mid-1980s. ${ }^{2}$ In order to avoid over-generalization, it is important to consider the artistic and institutional conditions that shaped the Moscow Conceptualist phenomenon in the visual arts, including generational and social groupings; artists' changing relationships to exhibition spaces and publics; and the shifting meaning of the aesthetic. ${ }^{3}$ The move away from expressionist abstraction, surrealism, and other Thaw-era modernisms in Russia began in the late 1960s and early 1970s among the Sretenskij Bul'var circle and the Sots-Art collaboration of Vitalij Komar and Aleksandr Melamid. ${ }^{4}$ This trend intensified after 1974, when a violent confrontation between authorities and artists over an unsanctioned public outdoor exhibition led to stronger divisions into distinct artistic groupings. ${ }^{5}$ One strand of Moscow Conceptualist activity in the visual arts can be traced from the overtly ironic Sots-Art tendencies of the collaborative duo Komar and Melamid to their students in the Nest group (Gnezdo; Gennadij Donskoj, Michail Rošal', and Viktor Skersis), whose brief creative alliance produced a number of works explicitly thematizing and critiquing political conditions in the Soviet Union. ${ }^{6}$ Another strand associated with the Collective Actions group (Kollektivnye dejstvija; Andrej Monastyrskij, Nikita Alekseev, Georgij Kizeval'ter, Nikolaj Panitkov, Elena Elagina, Igor' Makarevič, Sergej Romaško, and Sabine Hänsgen); and husband-and-wife teams Rimma and Valerij Gerlovin and Totart (Natal'ja Abalakova and Anatolij Žigalov), among others, assumed prominence alongside Kabakov and the Sretenskij Bul'var circle through their use of text, Cagean chance procedures, and the insertion of features of the everyday into overtly Modernist forms. By the beginning of the 1980s, nearly a decade of conceptually-oriented painting, albums, performances, and projects had produced an acknowledged conceptualist tradition centered around regular gatherings in artists' studios and apartments and organized actions outside the city. ${ }^{8}$ It was around this 
time that a still younger generation appeared on the Moscow scene. This new wave ushered in a distinctly lighter mood; their playful and pugnacious drawings and actions showed disdain for all seriousness and philosophical pretension, and their colorful paintings embraced painterly faktura (texture) and self-conscious naïveté. ${ }^{9}$

Moscow Conceptualism was far from a monolithic movement, and a concise definition and precise roster of artists have proved notoriously difficult to produce. ${ }^{10}$ Moreover, in-depth art historical studies and translations of primary sources into English are only just beginning to emerge, following the movement's initial introduction to a wider audience through gallery and museum exhibitions in the late-1980s and early-1990s and more recent shows in the last decade. ${ }^{11}$ This situation has so far resulted in a generalized treatment that has favored scope and clarity at the expense of a more complicated treatment of relationships between different parts of Moscow's unofficial art world and shifts in artists' strategies within the movement over time. What makes a subject like ironic laughter suggestive in this regard is that it has the potential to expose the variety of approaches and self-definitions among artists who would normally subscribe to a single group affiliation. A recent conversation between two key figures of Moscow Conceptualism, Nikolaj Panitkov and Andrej Monastyrskij, reveals one such fault-line at play within the movement.

Prompted by Monastyrskij on the subject of a distinct Moscow Conceptualist strategy or technique, Panitkov defines the method at work in the mid-to-late 1970 s as a kind of cultural combinatorics:

Н.П. [...] можно взять из этой культурной традиции предмет. [...] Взять, подумать сильно, взять из другой какой-то, попытаться совместить органично и вот вибрация создавала нечто третье, какой-то образ, и это была работа художников-концептуалистов.

N.P. [...] you can take an object from one cultural tradition. [...] Take it, think hard about it, take something from another, try to combine them organically, and then this vibration created some third thing, some kind of image, and this was the work of the artists-conceptualists.

For Panitkov, this carefully developed montage technique was eventually challenged at the end of the decade by the younger Muchomor (Toadstool) group, whose work he describes as a careless pastiche driven by parody and laughter:

Н.П. [...] Вдруг прибежали “Мухоморы”, посмотрели как мы все это делаем...

A.M. 78-й год, уже поздно. 
Н.П. Да, да. Ну, мы все это время разрабатывали метод... [...] Прибежали “Мухоморы”, посмотрели, похихикали и начали лепить одно на другое. И все, поехало тогда. Я понял, что с этим нельзя... они ничего не думают, они просто...

A.M. Это хохот начался.

Н.П. Да, это хохот и начали лепить одно на другое: рожу нарисовали, чего-то написали. И я в ужасе был от них...

A.M. Капустник начался.

Н.П. Просто в ужасе от такого бреда. Была интеллектуальная работа, Рубинштейн прекрасные тексты составлял, у тебя тоже были какие-то схемы. [...] Интересно было.

A.M. И акции тонкие, структурные...

Н.П. После этих “Мухоморов”, после того, как они заполнили пространство безумной, кретинской этой продукцией, я перестал что-либо понимать.

N.P. [...] All of a sudden, the Muchomors showed up, took a look at how we do all this...

A.M. 1978, that's late already.

N.P. Yes, yes. We were developing the method all this time [...] The Muchomors showed up, took a look, had a laugh, and began to stick one thing on top of the other. And that's when everything went downhill. I understood that you can have nothing to do with this... they do not think about anything, they simply...

A.M. That was the start of the laughter.

N.P. Yes, the laughter, and they began to stick one thing on top the other: drew a face, scribbled something. I was horror-stricken by them...

A.M. An amateur variety show.

N.P. Just horror-stricken from this kind of drivel. There had been intellectual work, [Lev] Rubinštejn composed fine texts, you too had some kind of diagrams. [...] Things were interesting.

A.M. The [Collective Actions'] actions were subtle, structural.

N.P. After these Muchomors, after they filled the space with their nonsensical, cretinous output, I ceased to understand anything whatsoever. $^{12}$

In this retrospective exchange Panitkov, with Monastyrskij's help, paints a picture of a discrete movement engaged in developing an aesthetic method to explore shared concerns. The work of the artists-conceptualists, in Panitkov's account, is distinguished by the deep intellectual effort of composing subtle, structural texts, diagrams, and actions to produce meaningful new images. The old notion of artistic craftsmanship is transformed into the intellectual craftsmanship of conceptualist montage whose effect is pure "vibration", uncoupled from specific cultural traditions and seemingly suspended in a purely aesthetic space. As if on cue, this delicate balance of conceptualist 
production is disrupted by a new wave of young artist-anarchists at the end of the decade, exemplified by the Muchomors, whose nonsensical laughter ruptures its pure effects.

Significantly, the word that Panitkov and Monastyrskij use to mark the difference between Conceptualism and this new wave is chóchot, laughter. Unlike smech, the more common word for laughter in Russian, chóchot has an explosive, corporeal quality that connotes a kind of infectious expressiveness. According to Vasmer's Etymological Dictionary, smech comes from the Proto-Slavic for "to laugh, joke, or ridicule", and is closely related to the words for "to smile" or "to cause to smile". Chóchot, on the other hand, is onomatopoetic. Like the verbs chochotát', chichíkat' (which Panitkov also applies in his polemic), and cháchat', which all mean "to laugh, to be a wellspring, or to bubble or seethe”, chóchot represents the physical emanation of laughter from the laugher's throat. ${ }^{13}$ If smech refers to an instance of individual amusement, in oneself or caused in another, then chóchot, as the very sound or instance of laughter, is implicitly public, a ringing in the audience's ears. ${ }^{14}$ Counter to the common identification of Moscow Conceptualism with ironic laughter, then, Panitkov presents the movement's seriousness and apparent depth in stark opposition to the Muchomors' shallow, exhibitionist chóchot. What is at stake in these different definitions of laughter? What is it about the Muchomors' particular form of laughter that is counter to subtlety and structure, that precludes Panitkov from "understanding anything whatsoever”? Is laughter the heart of Moscow Conceptualism or its undoing?

\section{Kabakov's "Jokes"}

While Panitkov's remarks are useful for casting light on certain generational and periodic distinctions in the movement, it would be a mistake to take them as objective history by ignoring the pointedness of his polemic. Public address, absurdism, and irony did not appear ex nihilo in the 1980s, but were prevalent in the earliest examples of Moscow Conceptualism by Il'ja Kabakov. Paintings, such as Ruka i reprodukcija Rejsdalja (Arm and a Reproduction of a Ruysdael, 1965); Golova s šarom (Head with a Balloon, 1965); and Avtomat $i$ cypljata (Machine Gun and Chicks, 1966), both physically transgress the flat surface of the picture plane into the viewer's space and display odd combinations of disparate elements that hover somewhere between Surrealism and Pop. Matthew Jesse Jackson has analyzed these and many of Kabakov's drawings from this time as walking the line between artworks and things-in-the-world, driving a sharp critique of both official Socialist Realist painting and the expressionist modernism of the sixties generation. ${ }^{15}$ It might be argued, however, that even more than his paintings, it is Kabakov's albums - a genre he invented around 1970-1971 and went on to explore throughout the better part of the decade - that were foundational to 
the aesthetics of Moscow Conceptualism. ${ }^{16}$ The albums' introduction of fictional characters like Sitting-in-the-Closet Primakov and Agonizing Surikov; insertion of commentaries from imaginary outside observers into the albums' narrative and pictorial structures; and performance in Kabakov's attic studio for audiences of artists and friends inaugurated some of Moscow Conceptualism's characteristic operations and exhibition strategies. For Kabakov, the albums were a way of bringing to the surface what he has called the "темы-образы” (theme-images) that had filled his mind since childhood, “"мифемы” комплексов, неврозоа-проблем или даже истеризмов” (“the 'mythemes' of complexes, neurotic problems, or even hystericism”). ${ }^{17} \mathrm{Al}$ though this language suggests a subjective plumbing of the artist's psyche, the settings, dramas, and everyday details depicted in the albums are firmly embedded in collective Soviet experience. ${ }^{18}$ One album in particular, Šutnik Gorochov (The Joker Gorochov; the second in the Desjat' personažej [Ten Characters] cycle, 1970-1975), addresses the theme of laughter directly. ${ }^{19}$ Its succession of visual puns and trick-the-eye coincidences serves up a series of curious occasions for audience laughter.

Alternatively jokey and sinister, this album resembles the kind of imaginative play with words and images that one might find in illustrated children's books. Bandits in a canyon turn into a fantasy of children bunking on tree branches. A woman from the Petrovsk region going to work at a kindergarten in 1973 turns up on the next page as the Countess Anna Myškova visiting the Zuevs' country estate in 1843 (see Figures 1-2). Indeed, prior to his emigration from the Soviet Union in 1988, Kabakov was a successful children's book illustrator, a position that afforded him a legitimate occupation, supplies, and a studio where he could make and show his work to fellow artists and friends. And like some of the best children's literature, Kabakov's albums are not as innocent as they at first appear. Despite the storybook imagery, Šutnik Gorochov hints at an ominous aspect of humor in Soviet society: the unstable range of potentially political readings and the danger of being informed upon for participating in their circulation. ${ }^{20}$ This is not noted outright, but a joke like Gorochov's opening gambit elicits a chill as the morbid political reality behind its laughter fails to conceal itself (see Figure 3):

\section{Смешно.}

- А вам почему не смешно?

- Я из другой организации.

Анекдот.

That's funny.

- How come you do not find it funny?

- I'm from a different organization.

A joke. ${ }^{21}$ 


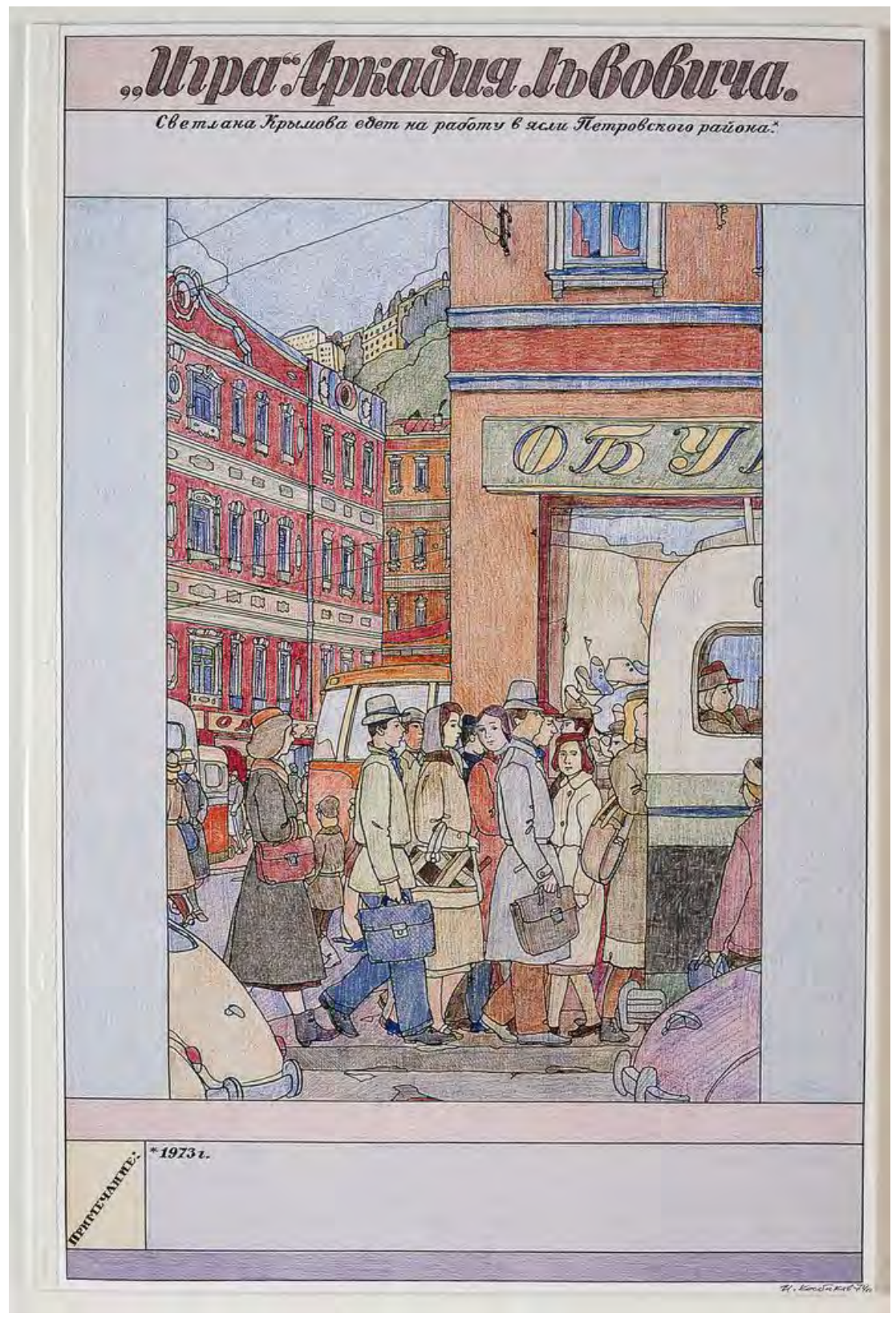

Fig. 1. Il’ja Kabakov, Svetlana Krymova edet na rabotu v jasli Petrovskogo rajona, 1974, from the album Šutnik Gorochov. 


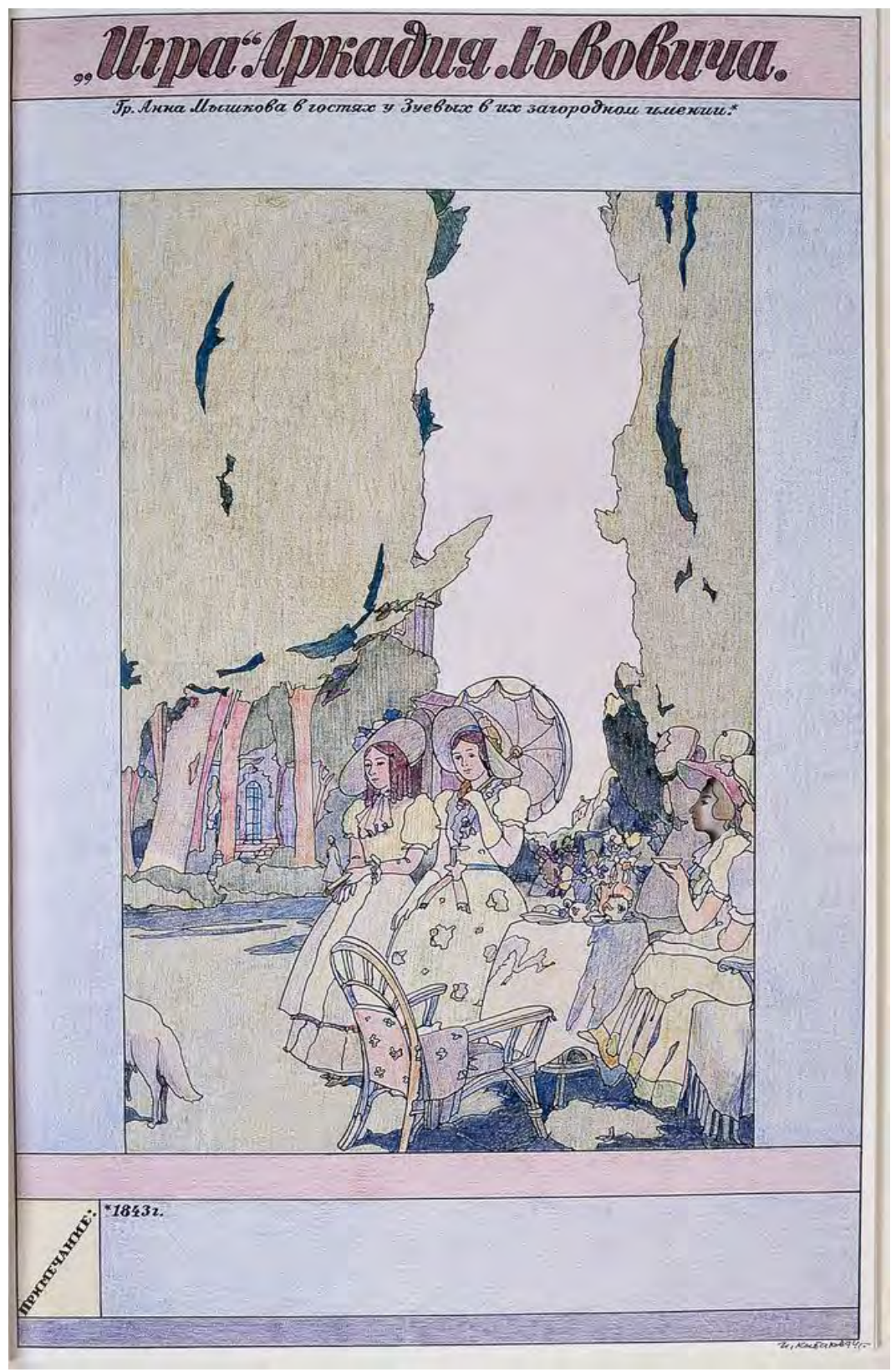

Fig. 2. Il’ja Kabakov, Gr. Anna Myškova v gostjach u Zuevych v ich zagorodnom imenii, 1974, from the album Šutnik Gorochov. 


\section{Jopoxob:}
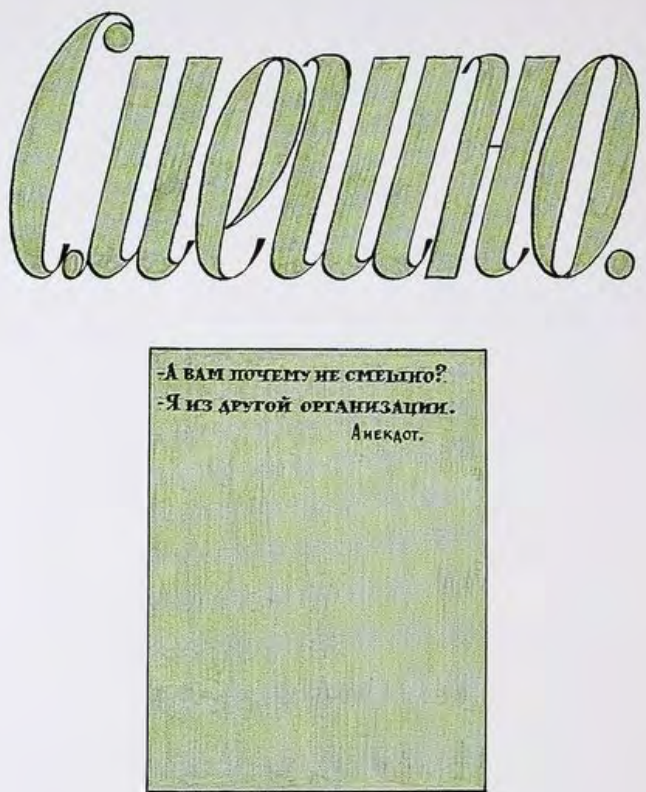

Fig. 3. Il’ja Kabakov, Smešno, 1973, from the album Šutnik Gorochov. 
Another joke, introducing Gorochov's first album borrows an incident from Mark Twain's satirical novel A Connecticut Yankee in King Arthur's Court (1889), in which a time-traveling hero convinces his medieval-era captors of his supernatural powers by "producing” a solar eclipse:

- “Солнце, закройся!” - произнес я громовым голосом.

Все подняли головы.

Ярко сияющий диск стал медленно уменьшаться.

(М. Твен, Янки при дворе Короля Артура)

“Sun, cover yourself!” I pronounced in a thunderous voice.

All lifted their heads.

The bright shining disk slowly began to diminish.

(M. Twain. A Connecticut Yankee in King Arthur's Court) ${ }^{22}$

Although Soviet authorities never challenged Twain's satire on political grounds, his hero's bold claim on the sun's power may have plausibly piqued Soviet ears when isolated in this way. Not only does Kabakov condense the entire "Eclipse" chapter into a dramatic kernel emphasizing one individual's claim to total power over natural phenomena and the allegiance of the masses, but there is a clear echo here with the radical Russian Futurist opera Pobeda nad solncem (Victory Over the Sun, 1913), not staged since 1920. Kabakov's imaginary commentator Lunina's curt declaration, "Мне Горохов не нравится" ("I do not like Gorochov"), might be the most politically correct response to such "dangerous" jokes and suspect associations for those seeking to avoid complications. ${ }^{23}$

For Kabakov's Moscow audience in the 1970s, however, such allusions to the cult of personality or the radical experiments of the Russian avantgarde would likely have come off as more dated than dangerous. ${ }^{24}$ Hardly an up-to-the-minute political satire, the entire album is narrated in a retrospective mode, surveying all of Soviet - and indeed human - history. Thematically, Desjat' personažej evokes "a bygone era”, its subject-matter and forms descending, as Jackson has noted, from the private life of nineteenthcentury Russia. ${ }^{25}$ Sutnik Gorochov's eponymous hero barely appears beyond the introductory page, where he relates his family's history of celebrated jokers and clowns. Their strange anecdotes and routines, which Gorochov carefully collects, comprise the album's three main sections. Aside from this brief introduction, Gorochov speaks only through the collected stories of his clowning relatives.

Many of Gorochov's family jokes hinge on a trick wherein a thing that seems one way, seen in a different light or from another angle, turns out to be another. In the first album, "Šutki" L'va Gleboviča (Lev Glebovič's "Jokes"), a series of fantastical scenes depicted on sheets of tracing paper are transformed into yet stranger scenes as the translucent pages are lifted back. 
In the second album, "Sovpadenija" L'va L'voviča (Lev L'vovič's "Coincidences"), odd and foreboding situations turn out to be a series of visual "coincidences" caused, we discover, by shifts in the observer's point of view. In the third album, "Igra" Arkadija L'voviča (Arkadij L'vovič's "Game"), each turn of the page reveals a different vista, plunging the viewer back in history, and finally concluding on the blank white page of Drevnie neizvestnye vremena (Ancient Unknown Times; see Figure 4). In the interspersed commentaries of Kašper, a fictional magazine editor, we hear of Gorochov's contributions of comedic material for the magazine's back pages. But strangely, even Kašper has never actually met Gorochov in the flesh, and he remains, like many of Kabakov's album characters, dissolved in the cacophony of voices, disappearing entirely by the end, as if by magic. ${ }^{26}$

What to make of this anachronistic collection of jokes, coincidences, and games, where the past comes hurtling back in all its quaint and antiquated forms? Who is Gorochov and why does he cling to fragments of the past at the expense of his own appearance in the present? Is this a reminder of trials endured (the memory of Stalinist terror made tame) or a reinvestment of old forms with new purpose (a productive mining of the preRevolutionary past)? In Jackson's reading, Gorochov's album is a contest between two inadequate epistemologies, "self-satisfied knowing and disruptive ignorance". ${ }^{27}$ In this world, any philosophical proposition is sooner or later swept away by an unruly joke, giving birth to more propositions swept away by more jokes in an infinite regress that "models the Futurist conception of art". ${ }^{28}$ In this reading, Gorochov, "playing anti-Hegel, suggests that art will no longer furnish the raw material for philosophy". ${ }^{29}$ Instead, philosophy and art are grist for the mill in the production of laughter.

Describing his album production, Kabakov enumerates the cultural мифемы (mythemes) that each of the albums in Desjat' personažej comes to embody. ${ }^{30}$ Sutnik, according to the list, expresses the idea of "Глупоость, непродвижение в глубину в шутке; ирония, которая только по виду многозначительна со всеми своими намеками. Особая пошлая эфемерность всякого остроумия" ("Stupidity, lack of movement into the depth of a joke, irony that only seems to be full of meaning with all of its innuendo. The special, low impermanence of any witticism”). ${ }^{31}$ As with Vladimir Nabokov's description of pošlost' as the "unobvious sham, [...] not only the obviously trashy but also the falsely important, the falsely beautiful, the falsely clever, the falsely attractive”, Kabakov's joker is falsely meaningful, falsely allusive, falsely significant of something beyond himself. ${ }^{32}$ Kommentarii Kogana (Kogan's Comment) from the concluding section, Obščij kommentarij (General Commentary), associates a similarly fallacious quality to jokes, an illusion of depth that runs up against the reality of shallowness. The fictional Kogan opines: 


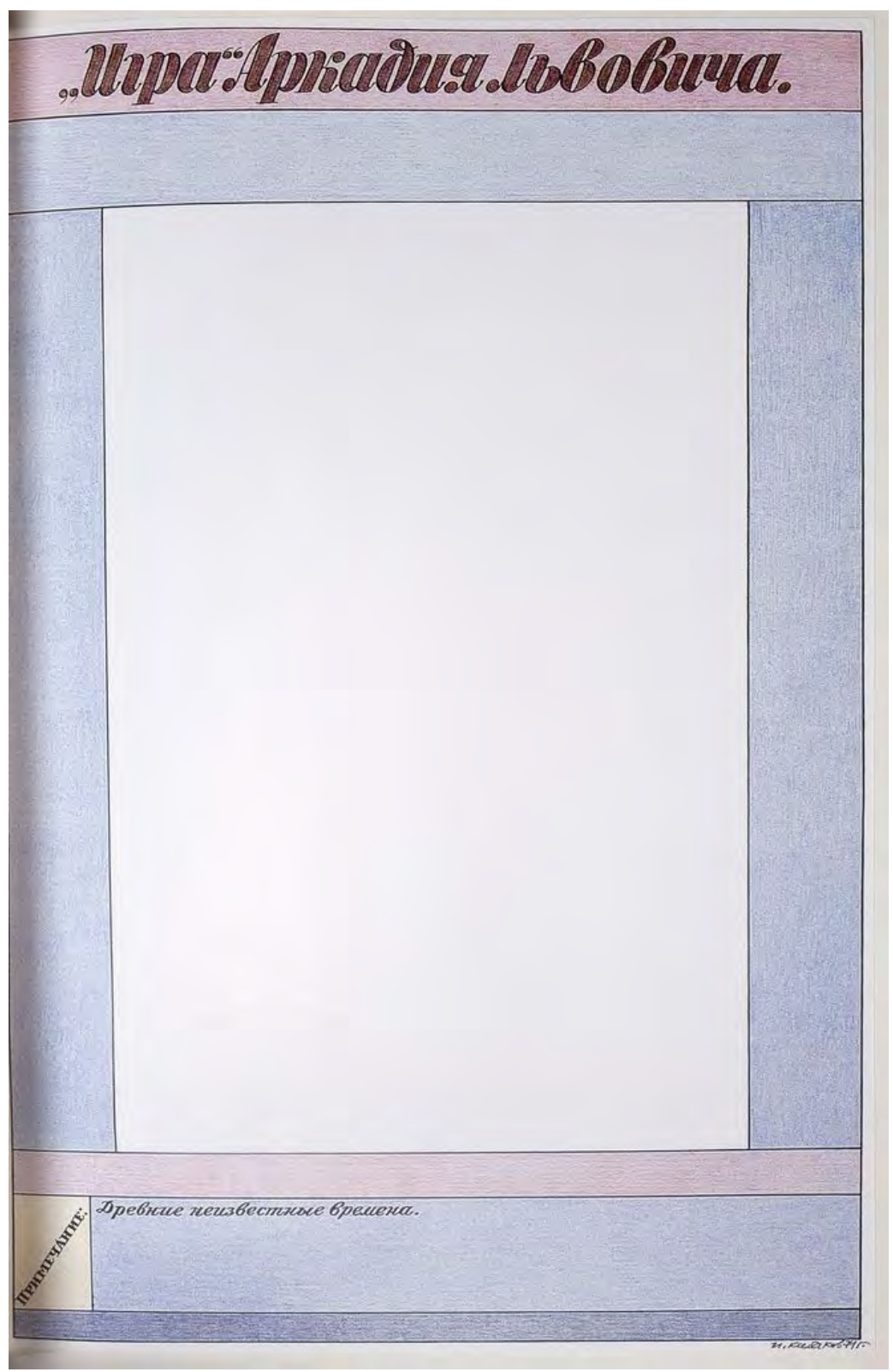

Fig. 4. Il'ja Kabakov, Drevnie neizvestnye vremena, 1974, from the album Šutnik Gorochov. 
Шутейство, если о нем говорить как о какой-то “философской установке”, просто состоит в том, что под самым верхним, доступным всем слоем смысла устанавливается другой, нижний, который прорывает, дискредитирует первый. Но к дальнейшему продвижению в глубину это не приводит, и все остается на поверхности, в этих двух слоях, которые бесконечно играют друг с другом.

Joking, if we talk about it as some kind of “philosophical proposition”, simply means that another, lower layer of meaning breaks through and discredits the first, uppermost surface layer of meaning that is accessible to everyone. But this does not lead to any further profundity, but rather, everything remains on the surface in these two layers which play endlessly with one another. ${ }^{33}$

If Gorochov's jokes are futuristic, it is an aimless sort of futurism, one in which laughter may well sweep away all it encounters, but remains powerless to make sense of the past or progress toward the future. It is instead an endless recapitulation, punctuating a present that teeters on the edge of triviality and outright bad taste.

Svetlana Boym has elaborated the idea of pošlost' - what Kabakov here links to shallowness, triviality, and laughter - as one side in the battle between "byt (everyday routine and stagnation), and bytie (spiritual being)". ${ }^{34}$ The stakes in this battle between pošlost' and its vehement critique are no less than "the definition of Russian identity, both national and cultural. The usage encompasses attitudes toward material culture and historical change, and it determines ethical values [...]". ${ }^{35}$ Gorochov's obsession with the past, the fragments of family lore, jokes, games, trifles, balloon rides, teacakes, incidents at a summer camp, flying rose-bushes, menacing flies, and fantastic fables would all seem to be permanent residents in the realm of pošlost', embedded in the world of nineteenth-century novels, Soviet children's books, jokes over tea, and the everyday domain of byt. If Kogan's theorizing is any indication, Šutnik Gorochov is a sly send-up of Soviet byt inflected in the key of popular literature and laughter. But rather than a futurist or revolutionary critique of bourgeois forms of life, Kabakov's laughter telescopes from present to past and back again, picking through the ruins of pre-Revolutionary and Soviet byt with the fascination of a garbage-picker or Walter Benjamin's book collector. ${ }^{36}$

\section{Metaphysical Comedy}

Amid this endless procession of jokes, there are moments in Gorochov's albums that go beyond the amusing coincidence or fantastical fable, that are not so easily displaced by the next gambit or put out of mind. These moments 
suggest the metaphysical, the mysteries underlying perceived and experienced reality, and in this way, they exceed the categories of byt or pošlost' and gesture toward bytie. They include: Šestikrylyj serafim (The SixWinged Seraphim, see Figure 5), a translucent sheet that, when lifted, reveals Slučaj v Ėrmitaže (The Incident at the Hermitage, see Figure 6), in which, according to the caption, "в четверг, 8 апреля, перед самым закрытием музея, восемь человек внезапно поднялись в воздух и образовали восьмиконечную звезду” (“on Thursday, April 8, right before the museum's closing, eight people suddenly lifted into the air and formed an eight-sided star"); the empty whiteness of Drevnie neizvestnye vremena (see Figure 4) concluding "Igra" Arkadija L'voviča; and Gorochov's mysterious disappearance at the end of Šrunik Gorochov, which piques, but does not quite confirm, our suspicion and Kašper's that Gorochov never really existed, and by extension, neither do we. ${ }^{37}$ These moments of mystery gesturing toward the sacred, the extra-historical, or simply inexplicable all signal the presence of another world beyond byt, the real possibility of depth, profundity, a world beyond joking or the play of surfaces.

Kabakov's album production dates entirely to the 1970s, with Desjat' personažej occupying his attention almost singularly in the first half of the decade. Kabakov writes of this time as being marked by a strange, widespread tendency toward spiritualism: "какое-то склонное к космизму сознание, особый интерес к высоким, неземным, сверхчувственным флюидам" ("а consciousness prone to cosmism, harboring a special interest in higher, unearthly, supersensible fluids"). ${ }^{38}$ The disillusionment following the crushing of the Prague Spring in 1968, the inability of the planned economy to meet the demands of an increasingly urban, educated population, and the abandonment of the grand historical teleology and utopian promises of previous decades all led to a growing malaise. ${ }^{39}$ For many, this spelled an inward turn in search of higher meaning outside party, history, or the prevailing atmosphere of consumerism, palpable, as Kabakov writes, in:

[...] необычайно метафизическом, странном, особом воздухе, даже можно сказать, климате, который царил как бы над Москвой с конца 60-х до середины 70-х годов и который как бы захватил умы или, точнее сказать, сознание определенной части художественной, и не только художественной, “общественности”.

[...] an extraordinarily metaphysical, strange, particular air, or we can even say climate, which reigned over Moscow from the end of the 1960s and until the middle of the 1970s, and which seemed to have seized the minds, or more precisely, the consciousness of a particular part of the artistic, and not just artistic, "public sphere". 


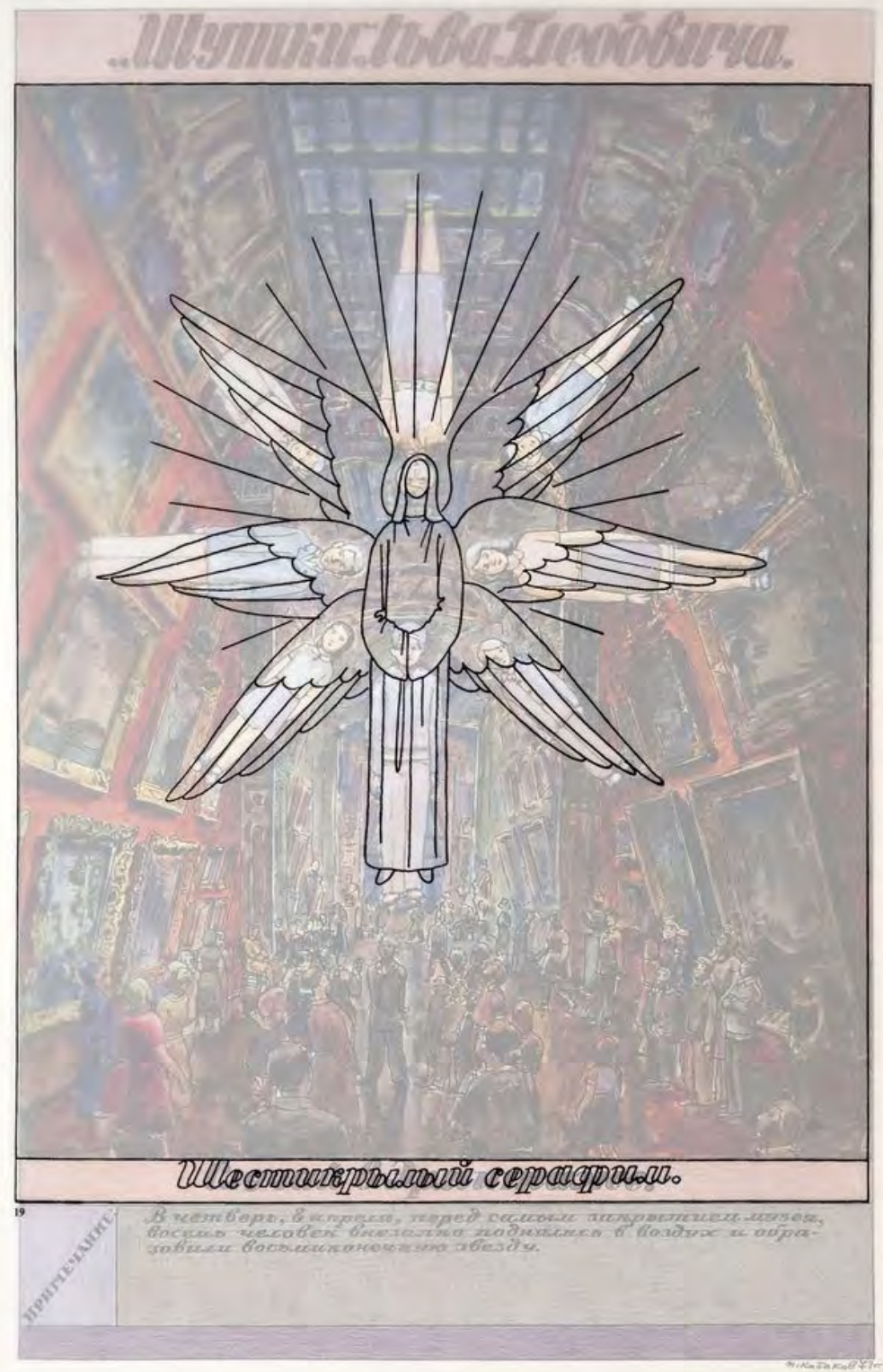

Fig. 5. Il'ja Kabakov, Šestikrylyj serafim, 1973, from the album Šutnik Gorochov. 


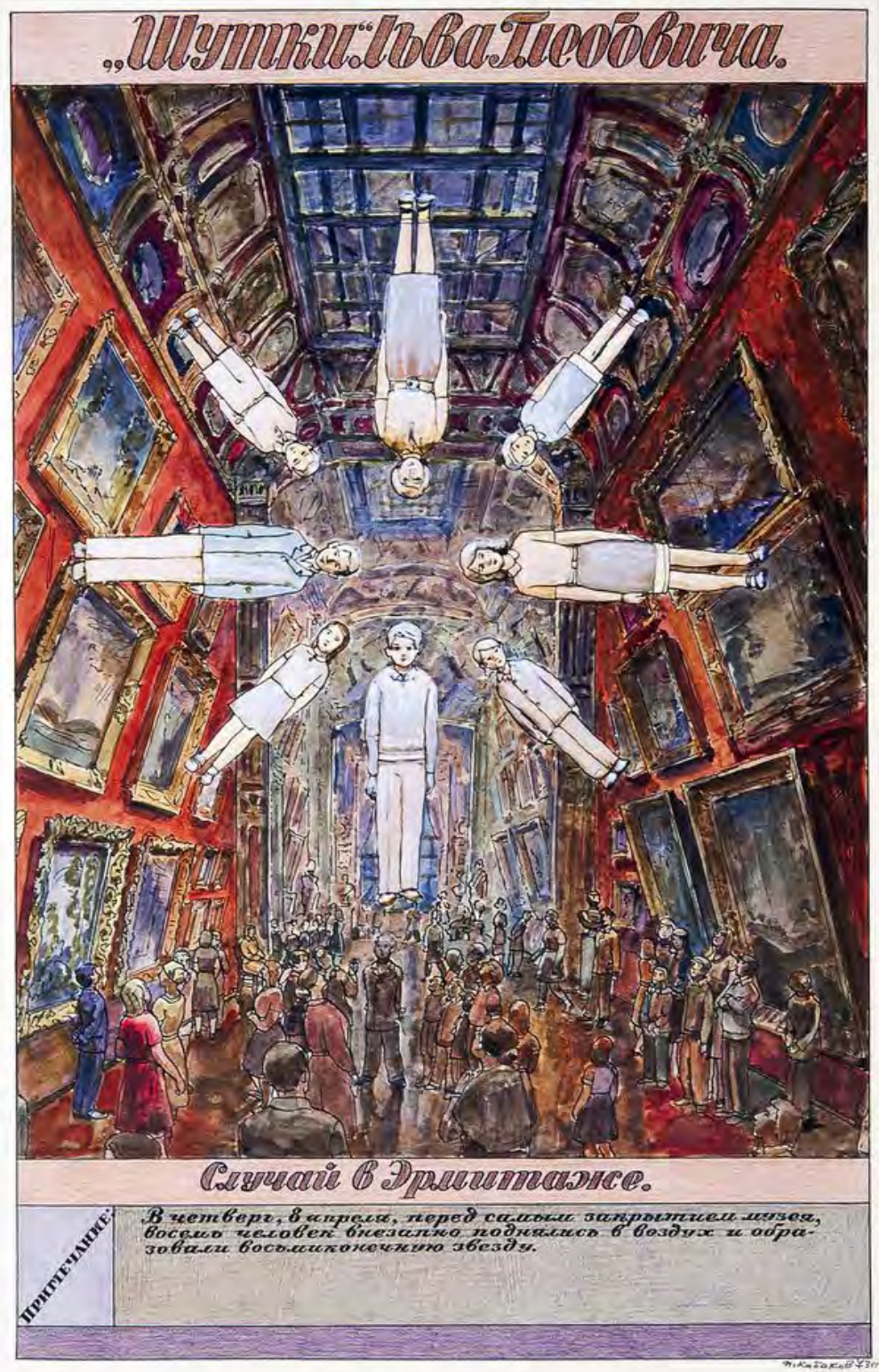

Fig. 6. Il’ja Kabakov, Slučaj v Ėrmitaže, 1973, from the album Šutnik Gorochov. 
For Kabakov and his circle, this spiritualism and metaphysical mood expressed itself both in the never-ending conversations that suffused their frequent gatherings and in works of a wide variety of aesthetic positions, from abstract painting to conceptual albums of the type I have been describing. What might be read as the pure irony of Kabakov's meticulous reproduction of Soviet communal byt, in the unofficial artistic culture of the early 1970s, cannot be read without considering a metaphysical dimension that transcends the frame of the artwork.

This dynamic of byt/bytie underpins the performances of Collective Actions (Kollektivnye dejstvija), a group of Moscow Conceptualists of a slightly younger generation than Kabakov, who began staging minimal, antitheatrical actions in the fields and forests on the edge of Moscow in the spring of 1976. Collective Actions events always began with invitations requesting the viewers' presence at a determined time and place. With no knowledge of what was to come, the invitees experienced a sense of anticipation as they journeyed by commuter train and made their way through the landscape to arrive at the place of action. The action itself - or rather, the demonstrational part of the action - was rarely very long or especially eventful. In most actions, such simple phenomena as the appearance of a figure in the distance, movement across a field, or the pulling of a rope out of the forest became the focus of intensified attention that gave the performances at times the sense of something extraordinary taking place.

Two early actions, Komedija (Comedy; October 2, 1977) and Tretij variant (The Third Variant; May 28, 1978) could be considered close relatives of Šutnik Gorochov for the ways that they restaged tropes of popular amusement to oscillate between ordinary, even pošlyj laughter and the metaphysical experience of intensified sensorial perception. In Komedija, two figures - one tall and draped in an ochre-colored cloth, the other shorter, dressed in street clothes, and following behind holding the draped figure's train - appeared on an empty field and began to move in the direction of the audience. When approximately 80 meters away, they stopped to face the viewers, the second figure climbed under the drapery, and they continued to move as one across the field. When the draped figure stopped again and lifted the drapery, the second figure was no longer there (once hidden under the drapery, the second participant had lain down in a ditch out of the audience's sight). Having removed his costume, the standing figure turned and left the field. The other figure remained in the ditch until the audience departed (see Figure 7) ${ }^{41}$ A similar scene of conjury played out in Tretij variant. A figure draped in violet appeared from the forest, crossed the field, and lay down in a ditch. After a few minutes, a second figure, also draped in violet but with a red balloon for a head, appeared from a ditch in a different part of the field. He then proceeded to pierce the balloon, producing a cloud of white dust, and lay back down. At that moment, the first figure stood up from the original 
ditch, now wearing ordinary street clothes, filled the ditch in with dirt, and disappeared into the forest from which he had come (see Figure 8). ${ }^{42}$

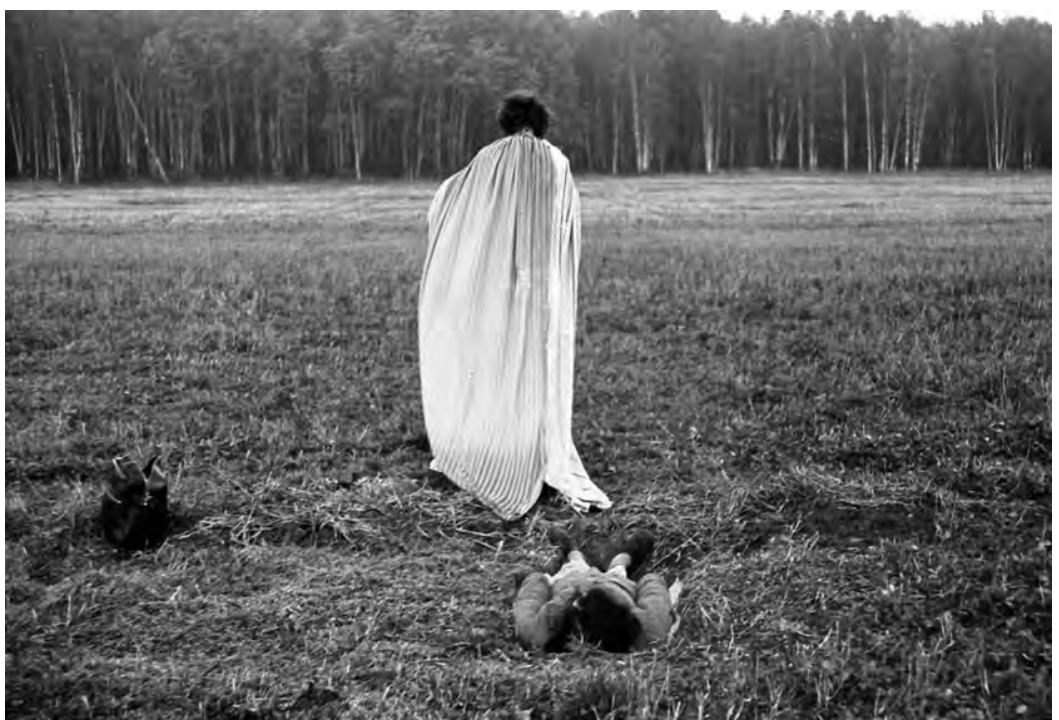

Fig. 7. Kollektivnye dejstvija, Komedija, October 2, 1977.

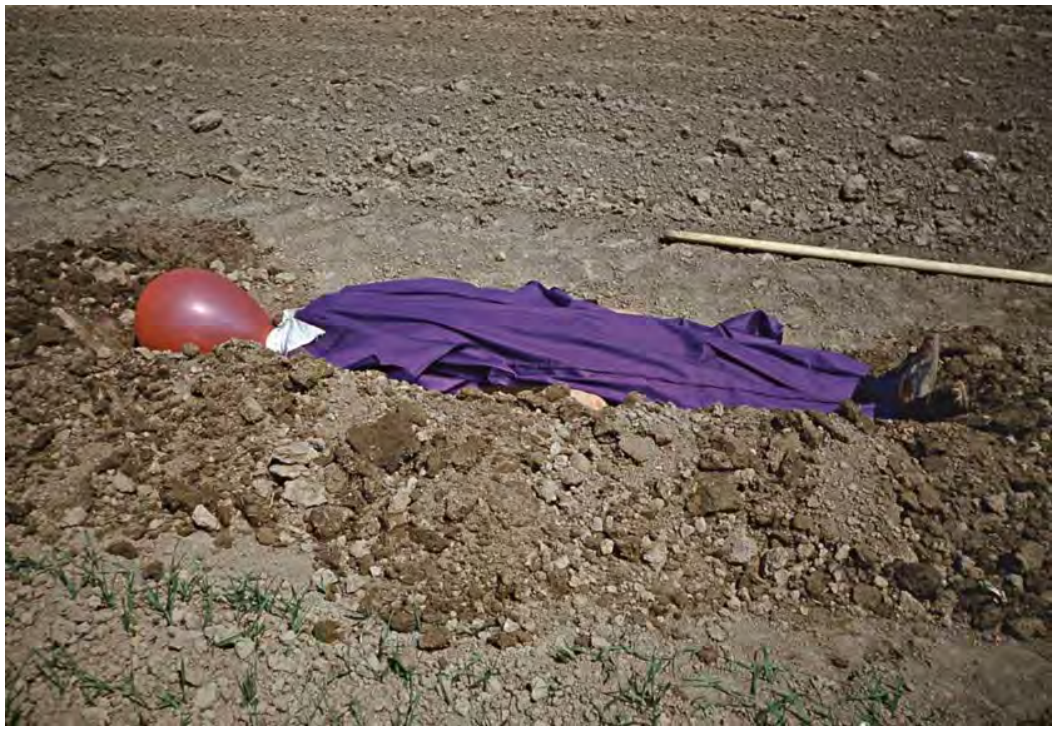

Fig. 8. Kollektivnye dejstvija, Tretij variant, May 28, 1978. 
In the first volume of Collective Actions' documentary materials, Poezdki za gorod (Trips out of the City), the group describes these early performances as anti-demonstrational settings for meditation on the viewer's own consciousness. "[У] нас нет задачи что-либо 'показать' участникамзрителям," they write in the preface. "Задача состоит в том, чтобы сохранить впечатление от ожидания как от важного, значимого события" ("Our goal is not to 'show' something to the viewer-participants. The goal consists in preserving the sense of anticipation as of an important, meaningful event"). ${ }^{43}$ More than any of the group's other actions, Komedija and Tretij variant underscore the disjunction between theatricality and spiritual experience, between "showing something" to an audience and inviting the audience to experience an "important and meaningful event". Like Gorochov's family clowns, Komedija and Tretij variant's draped figures, stagelike situations, and sleight-of-hand illusions evoke popular entertainments or Commedia dell'arte spectacles. The spectacle, however, like Gorochov's joking, serves as a decoy. “[T]о, что нам демонстрировалось," the preface continues, "на самом деле было демонстрацией нашего восприятия - и ничего больше" ("The thing that was being demonstrated was in reality a demonstration of our perception and nothing else"). ${ }^{44}$ In this way, the spectacle shapes the outward form of the artwork and mediates reception in a familiar, even clichéd way, while at the same time pointing to the possibility of some deeper meaning beyond these habitual and culturally codified forms of reception.

Acknowledging the limits of artistic experience to access the spiritual Gorochov's disappearance, the empty album page - Collective Actions write:

Следует оговориться, что в этом предисловии мы рассматриваем только одну, поверхностную часть всей ситуации, то есть “для зрителя” и более менее связанную с эстетическими проблемами. Внутренний смысл ее, связанный с главной целью акций, а именно, получением определенного духовного опьта, по существу своему не знакового, и который имеет реальное значение исключительно для действующих на поле устроителей, здесь не рассматривается.

We should clarify that in this preface, we are considering only one, superficial part of the entire situation, the part "for the viewers" that is more or less related to aesthetic problems. Its inner meaning, which is related to the main goal of the action, namely, the attainment of a particular spiritual experience - in its essence not signifiable - and which has real significance exclusively for those organizers acting in the field, is not considered here. ${ }^{45}$ 
Here, the limits of the aesthetic are revealed. They mask a more profound level of experience (bytie) that does not yield to documentation or analysis and is only gestured at by the mundane act of watching figures move through a field or laughing at the popping of a red balloon.

The Conceptualist turn in Moscow in the 1970s was more complicated than either its name or the notion of ironic subversion would imply. As Jackson has argued, it was, in one sense, a reaction to the prevailing artistic situation in Moscow, a working-out of positions “in a no-man's-land between an unattainable modernist subjectivity and the awfulness of Soviet reality".46 The struggle with metaphysical questions pervaded many corners of unofficial life, from underground religious fellowships to the spiritually-infused abstract paintings of Michail Švarcman or Ėduard Štejnberg. ${ }^{47}$ For Kabakov, Collective Actions, and their circle, however, the metaphysical represented a separate realm, invoked in, but essentially beyond the reach of the aesthetic. If the utopian impulse of Malevič's Black Square was once again decoupled from the practical imperatives of political and cultural revolution in its postwar reception, this utopianism did not find a direct counterpart in Moscow Conceptualism. ${ }^{48}$ While alluding to the clichés of everyday Soviet life in what can be called "muted irony”, Kabakov's albums, Collective Actions' performances, and many other examples of Moscow Conceptualist activity, carved out spaces for non-instrumental aesthetic experience and spiritual feeling within the Soviet everyday. ${ }^{49}$ Through such "useless actions" as turning the page of an album or watching figures in a field, this strain of Moscow Conceptualism suggested a re-investment of everyday perception with a fullness and meaningfulness that seemed to be lacking in the "cold, grey, indistinct absurdity" of Moscow in the 1970s. ${ }^{50}$

\section{Senseless Laughter}

While laughter may have attended the performance of Kabakov's albums or Collective Actions' events and enlivened the circle's social atmosphere, it would be misleading to say that laughter comprised their primary aesthetic strategy, as the previous examples demonstrate. However, the end of the 1970 s and beginning of the 1980s saw a turning point in unofficial art in Moscow away from the seriousness of "black-and-white conceptualism" of the concluding decade and toward a mood of giddy, multicolored festivity. Nikita Alekseev (another member of Collective Actions) recalls these years as a time of “плясание и тусовка" (“dancing and socializing”). ${ }^{51} \mathrm{As} \mathrm{Pa}-$ nitkov suggests, the change was hastened by the appearance of a new generation, often referred to as the “Ньию-вэв” (New-wave), for whom Kabakov, Collective Actions, and their circle were a formidable, but outmoded tradition. The most radical of this youth wave were Muchomor, a group of five young men refusing to be called artists and resembling “гикающую 
толпу новобранцев” (“а hooting crowd of new conscripts”) who wrote poems, painted each other's portraits, staged performances, sang songs, and produced suitcases full of drawings, lyrics, and hand-made books. ${ }^{52}$ Deriving their name from the Amanita muscaria, commonly known as the fly agaric mushroom ( "мухомор" in Russian), the Muchomors pursued a carnivalesque strategy that drew on the countercultural undertones of the well-known entheogen and subject of popular culture and children's books.

With laughter as an all-pervasive tactic, the Muchomors mounted a two-pronged attack on both Soviet mass culture in its verbal and visual forms and on the unofficial artistic tradition from which they had sprung and within which they located themselves. In this way, they combined images ironically mimicking official propaganda with mocking treatments of their artistic predecessors, who were still very much present. One of the Moscow art world's earliest encounters with this outrageous, undifferentiating laughter took place in the spring of 1979 at a gathering of the "seminar", which was held regularly at the apartment of Alik Cačko and attracted many of Moscow's unofficial luminaries, including Kabakov, Bulatov, Čujkov, poets Dmitrij Prigov, Lev Rubinštejn, and Vsevolod Nekrasov, critic Boris Grojs, among others. ${ }^{53}$ The five young members of the group, brought by the Gerlovins and Monastyrskij to host a "literary-artistic evening", proceeded to stage a merry jubilee for the fictional lieutenant Rževskij, hero of drama and sexually explicit jokes, complete with crude pictures, readings in honor of Rževskij, and tape recordings propagandizing the group. ${ }^{54}$ Over the next five years, the group continued its assaults, staging performances closely resembling those of Collective Actions, but with a playfully sardonic edge.

In one performance, Raskopki (Excavation; May 27, 1979), the meditative mysticism and obsession with documentation of Collective Actions' Komedija or Tretij variant took on a shocking tone when a large group of viewers, invited to a field to dig for buried treasure, unearthed a coffin containing the nearly suffocating Muchomor member, Sven Gundlach, feverishly taking down his immediate impressions (see Figures 9-10). ${ }^{55}$ Another action, Rasstrel (nakazanie) (Firing Squad [Punishment]; September 15, 1979), turned its aggression on the audience, when members of the group wearing army uniforms complete with rifles and gas masks marched all 67 invitees for an hour, choosing one nineteen-year-old audience member to be "punished" by firing squad. ${ }^{56}$ The "guilty party" was then taken into the forest and an actual rifle shot was heard, leaving the audience extremely disturbed. For many in the circle, these scandalous actions were beyond the pale of what could be considered art. For Gundlach, however, proper artistic boundaries were beside the point. He experienced the 1970s as a crisis, “начиная с тенденции превратить искусство в псевдорелигиозную практику и кончая с повальной эмиграцией" ("beginning with the tendency to transform art into a pseudo-religious practice and ending with the epidemic of emigration”). Not 
only that, but Gundlach had experienced the horror of being pursued by the authorities from the time he was an adolescent, when he had been targeted to become an informant by the KGB. ${ }^{57}$ To work in the style of the "'героический период’ невещественного, неосязаемого, неуловимого” (“'heroic period' of the immaterial, the intangible, the elusive"), so emblematic of 1970s Conceptualism, was no longer possible. ${ }^{58}$

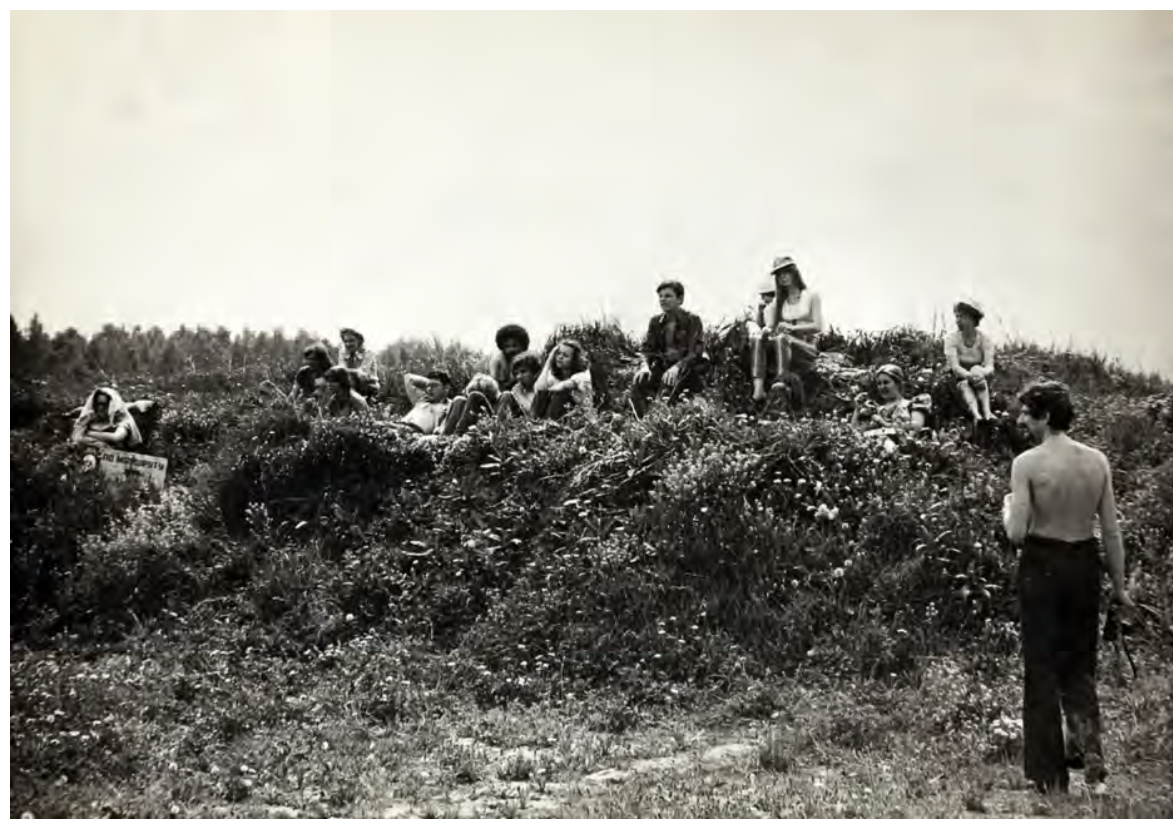

Fig. 9. Muchomor, Raskopki, May 27, 1979.

The change of mood around the turn of the 1980s was palpable not just in art, but in society more broadly. The Soviet invasion of Afghanistan in December 1979, the preparations for the Moscow Olympics in 1980, and the rise of the Solidarity movement in Poland in the same year all contributed to renewed restrictions on public life in Moscow and a disciplinary attitude to underground culture not seen since the early 1970 s. ${ }^{59}$ Artists who had been published in $A-Y a$ were subject to close surveillance and warned to have nothing to do with the journal. ${ }^{60}$ The Aptart gallery, opened in Alekseev's apartment in October 1982 and housing the pageant-like installations of the young New-wavers, suddenly came under official scrutiny and closed after only five months (see Figure 11) ${ }^{61}$ Alekseev and Michail Fedorov-Rošal', an Aptart collaborator, sustained home searches and interrogations. By 1984, 
three Muchomors had been conscripted into the army and forced to leave Moscow. ${ }^{62}$

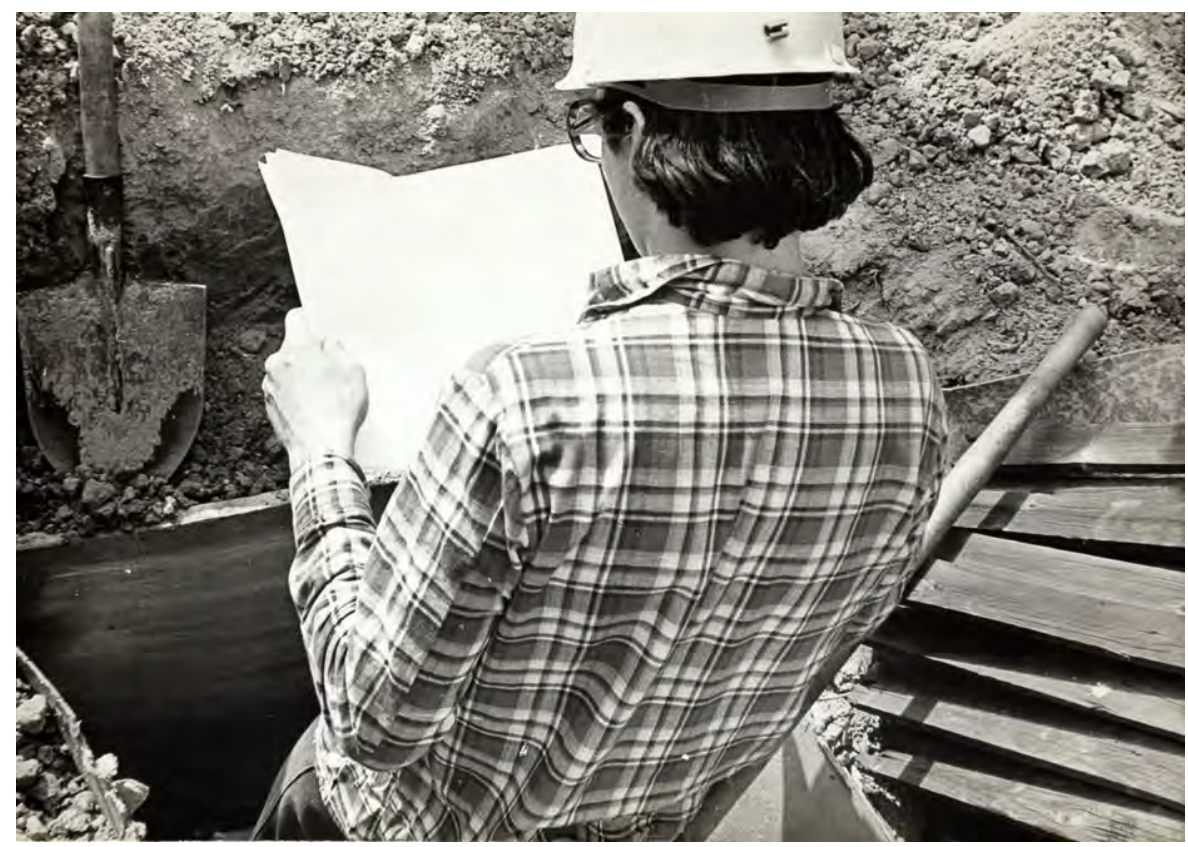

Fig. 10. Muchomor, Raskopki, May 27, 1979.

It is no surprise, then, that political themes began to appear in Newwave artwork in a way not generally seen in the 1970s. Muchomor actions alluding to Soviet militarism and the threat of nuclear war directly addressed the disparity between Soviet rhetoric and political reality. ${ }^{63}$ The Soviet attack on a South Korean passenger plane in September 1983 inspired an Aptart exhibition Pobeda nad solncem (Victory over the Sun). ${ }^{64}$ Even some of the most seemingly juvenile works, like Vadim Zacharov's Sloniki (Little Elephants; 1981-1982), allude to the politics at the core of Soviet experience (see Figures 12-13). In this performance, represented by a set of four blackand-white photographs set in a plain domestic interior, Zacharov, crouching in a corner and dressed in the shirt and tie of a fashionable young man, employs various methods of "neutralizing" a set of porcelain elephant figurines ubiquitous in Soviet domestic interiors. He tries incorporating them into his body (stuffing them in his ears, nose, and mouth); integrating his body into their order (serving as their display shelf); and pushing them away (throwing them up in the air, only to have them fall back down on his chest). 
But in the end, the elephants prove too strong a symbol, and sullen-faced, he declares, “любое сопротивление слонам бесполезно. Слоны мешают жить" ("any resistance to elephants is futile. Elephants get in the way of life"). ${ }^{65}$ The war against domestic trash, including faience figurines, "fatbellied" petit-bourgeois furniture, and porcelain elephants, was, as Boym has argued, a crucial front in the early Soviet construction of New Byt, the new Communist everyday life. ${ }^{66}$ Parodying this battle against bourgeois kitsch, Zacharov's Sloniki are paradigmatic of the younger generation's attitude to Revolutionary politics. Unlike Sots-art, which sought to deconstruct the codes of Soviet ideology, the carnivalesque quality of Muchomor and Aptart spectacles went further by destroying sense as such, plunging viewers into a visual and verbal confusion that elicited intense emotional reactions spanning both laughter and outrage. While ridiculing the earnestness of Revolutionary fervor, their works rejected escape to higher realms through the aesthetic. Pinning the viewer with a look of deadpan derision, Zacharov knows with the clarity of hindsight that escape is futile. Elephants are a problem for which the aesthetic has little recourse.

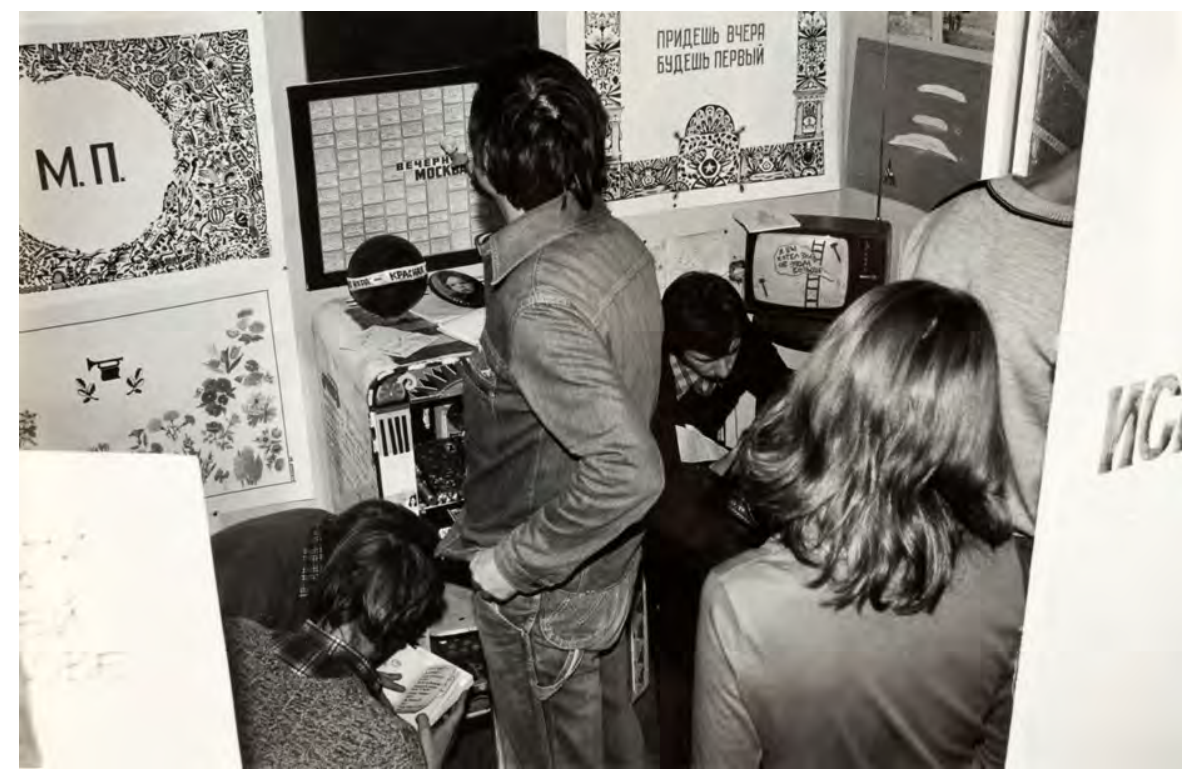

Fig. 11. Aptart, installation view. 


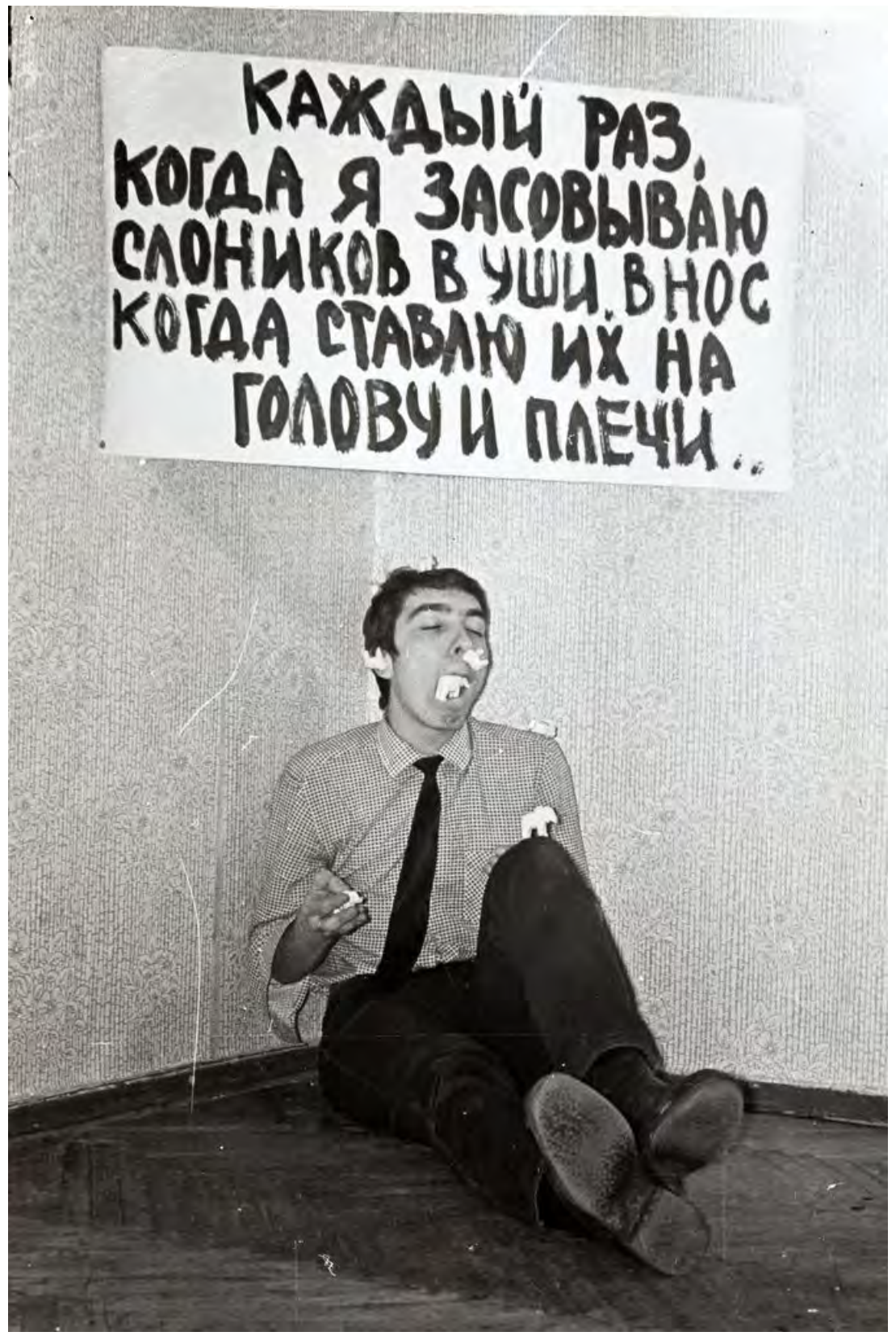

Fig. 12. Vadim Zacharov, Sloniki, 1981-1982. 


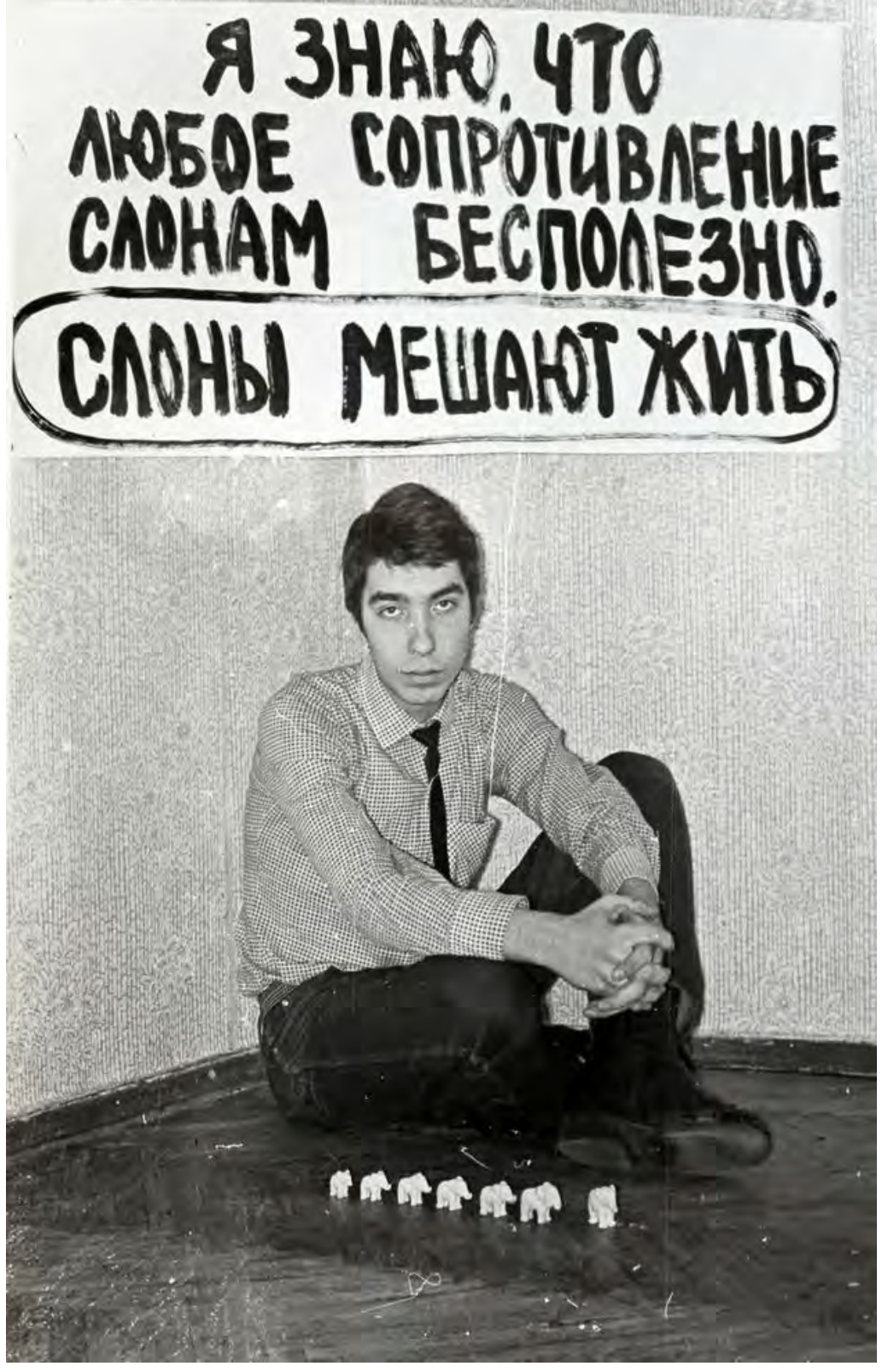

Fig. 13. Vadim Zacharov, Sloniki, 1981-1982. 


\section{Conclusion}

In his study of Rabelais, Michail Bachtin associates carnival laughter with the material body and with the breaking down of old, petrified forms. "Laughter degrades and materializes," he writes. ${ }^{67}$ It opposes the seriousness of official culture with sensuous and playful elements whose parody of the world reveals its relativity and foments its rebirth. ${ }^{68}$ Extending Bachtin's observations into the sphere of cultural politics, Peter Sloterdijk suggests a return to the kynical tradition of aggressive and shameless bodily gestures ("the kynic farts, shits, pisses, masturbates on the street, before the eyes of the Athenian market”) as the materialist deployment of laughter and parody in the service of social criticism and resistance to hegemonic power. ${ }^{69}$ Both theorists see laughter as a potentially active force of political resistance emerging from the unofficial realm in the face of established, repressive institutional structures.

The discursive field on which the New-wave generation of Moscow Conceptualists operated was two-fold. On one level, it responded to the local artistic discourse of the Moscow Conceptualist circle, articulated in artworks, actions, constant discussions in apartments and studios, and texts passed around in samizdat manuscripts and sometimes published in the West. ${ }^{70}$ On another, like the older generation, it addressed the broader ideological field of Soviet everyday life and institutions, including official language and representations as well as the ordinary conditions of byt. That the younger generation turned to laughter as a strategy on both fronts marked a significant change in the relationship between art and politics in Moscow Conceptualist art. If Kabakov and Collective Actions could be said to have worked in the gap between art and life - by straddling works of art and ordinary objects, or significant, meaningful actions in the field and everyday being in the world to gesture toward and preserve space for the metaphysical, then Muchomor and the Aptart movement seemed to insist on obliterating the distinction altogether through the kynic strategy of sense-destroying laughter.

Anthropologist Alexei Yurchak identifies a particular sort of absurd, ironic laughter as both prevalent in and specific to late-Soviet culture. ${ }^{71} \mathrm{Al}-$ though these humorous genres could operate in aesthetic fields (Yurchak mentions Mit'ki and the Necrorealists, though Muchomor would also qualify), he argues for a more expansive reading of ironic laughter as a "symptom of the broader cultural shifts that occurred in late-Soviet society" ${ }^{72}$ Arising from the encounter with the paradoxes of everyday Soviet life, this form of humor "refus[ed] to accept any boundary between seriousness and humor, support and opposition, sense and nonsense" and instead "engaged with the same paradoxes and discontinuities of the system, exposing them, reproducing them, changing their meanings, and pushing them further". ${ }^{73}$ This characterization of a radical subjection of everyday life and art to ironic procedures describes well the activities of Muchomor and Aptart. What unnerved 
Panitkov about these activities - Muchomor's indifference to artistic boundaries or standards, their "unstoppable energy" that refused to discriminate between aesthetic practice, political propaganda, and kitsch - was precisely what, according to Yurchak and consistent with Bachtin and Sloterdijk, endowed this kind of humor with its critical edge.

Here, finally, lies the crux of Panitkov's objection to Muchomor, the stakes of his passionate polemic. If senseless laughter levels all categories, disregards boundaries, and refuses to play by the rules, then Moscow Conceptualism itself is yet another category to be flaunted, another "armored, self-preserving, and rationalizing ego" that the kynic body subjects to its attack. ${ }^{74}$ In this sense, Panitkov is correct in his assessment that the Muchomors' senseless laughter spelled the downfall of Moscow Conceptualism, even while the two generations socialized in the same circles, distributed their texts in the same editions, and showed their work in the same exhibition spaces. That the Muchomors no longer respected the aesthetic as an autonomous sphere with important spiritual/metaphysical potential, however, means that such a downfall was of little concern in any case. If we look at the bigger picture, however, there were many factors that contributed to a shift away from Conceptualist strategies as they were practiced in the 1970s, the most significant of which were the ability to travel to the West and the opening up of the unofficial art world to the Western art market in the midand late-1980s. Moreover, both Muchomor and Aptart were fairly short-lived phenomena cut short by KGB pressure. I would argue that it was not internal conflicts or artistic debates - useless action versus senseless laughter - that destroyed Moscow Conceptualism, but outside forces, like emigration, government pressure in the early 1980s, and the Western art market, that ultimately spelled the end of unofficial art as a whole.

\section{NOTES}

1 See for example, Groys, Hollein, Fontán del Junco (2008).

2 I should say outright that my interest here lies in Moscow Conceptualism in visual and performance art, not poetry or literary fiction. This is a somewhat artificial distinction, since artists and poets moved in overlapping circles and maintained a close dialogue. For various reasons, however, it is a distinction that has prevailed in the literature and produced two different bodies of criticism with rather different emphases. (Scholarship on literary conceptualism, for example, tends to link it more closely with Sots-Art and focuses on issues such as literary genres, discourse analysis, and poetics.) On literary con- 
ceptualism, see Epstein, Genis, Vladiv-Glover (1999); Lipovetsky (1999); Balina, Condee, Dobrenko (2000).

"Moscow Conceptualism" is a widely accepted variation of the term first coined by Boris Groys in his article 'Moscow Romantic Conceptualism' (1979: 3-11). See also Groys (2006: 408-409).

The Sretenskij Bul'var circle loosely included Ėrik Bulatov, Il'ja Kabakov, Viktor Pivovarov, Oleg Vasil'ev, Ulo Sooster, Ivan Čujkov, Ėduard Štejnberg, and Vladimir Jankilevskij. See Alpatova, Taločkin, Tamruči (2005:

5 138).

5 For more on this incident, whose dramatic circumstances and coverage in the Western press earned it the name Bulldozer Exhibition, see Hoptman, Pospiszyl (2002: 65-77); Glezer (1977).

On Komar and Melamid's Sots-Art Conceptualism, see Ratcliff (1988). On The Nest, see Alpatova (2008).

7 For more on individual artists and groups, see Alpatova et al. (2005); Margarita Tupitsyn (1989); Degot' (2000); Viktor Tupitsyn (2009). On Moscow Conceptualism specifically, see Bobrinskaja (1994); Tamruchi (1995); Degot', Zacharov (2005); Groys et al. (2008); Jackson (2010); Groys (2010). The desire to document this tradition gave birth to MANI, Moskovskij archiv novogo iskusstva (Moscow Archive of New Art), whose first volume came out in February 1981.

This new wave included the Muchomor (Toadstool) group (Sven Gundlach, Aleksej Kamenskij, Sergej and Vladimir Mironenko, and Konstantin Zvezdočetov); SZ (Viktor Skersis and Vadim Zacharov); Jurij Al'bert; as well as other artists associated with the Aptart gallery. See M. Tupitsyn (1989: 98115); Obuchova (2004); and Silaeva (2007).

Compare, for example, the list of contributors to MANI or $A-Y a$ with the slightly different artists considered by Bobrinskaja (1994), Degot', Zacharov (2005), and Groys et al. (2008).

The various waves of Moscow Conceptualism's reception are a subject that deserves separate consideration. This exhibition history includes, among others, Between Spring and Summer: Soviet Conceptual Art in the Era of Late Communism (Tacoma Art Museum, Tacoma, WA and The Institute of Contemporary Art, Boston, 1990); Moskauer Konzeptualismus: Sammlung Haralampi G. Oroschakoff \& Sammlung, Verlag und Archiv Vadim Zakharov (Kupferstichkabinett, Berlin, 2003); Angels of History: Moscow Conceptualism and Its Influence (Museum van Hedendaagse Kunst, Antwerpen, 2005); Total Enlightenment: Conceptual Art in Moscow, 1960-1990 (Schirn Kunsthalle, Frankfurt am Main; Fundación Juan March, Madrid, 2009); Field of Action: The Moscow Conceptual School in Context, 1970s-1980s (Ekaterina Cultural Foundation, Moscow; Calvert 22, London, 2010-2011).

See Monastyrskij, Panitkov (2010). Unless otherwise indicated, all translations of Russian texts are my own. 
13 See smejus' and chóchot in Vasmer's Etymological Dictionary (1998). Compare also to the English "ha ha", meaning "to laugh aloud", in the Oxford English Dictionary (2012).

The Russian Futurist echo here is of course to Velimir Chlebnikov's 'Zaklinanie smechom' (1909), which belies the smech/chóchot distinction somewhat. Nonetheless, as Anca Parvulescu reads it, Chlebnikov's use of smech acquires its incantatory, public quality in part by the onomatopoeia produced through the repetition of $c h$ sounds, a condition that is already present in chóchot. See Parvulescu (2010: 1-4). Jackson (2010: 64-66, 74-75).

See Il’ja Kabakov (2008: 121-151, 356-357).

Ibid., 136-137.

On the collective in Soviet unofficial art and Moscow Conceptualism, see V. Tupitsyn (2009).

The dating of the albums varies slightly by source. In $60-70-e . .$. , Kabakov gives, variously, 1970-1975 and 1972-1975 as the dates for the Desjat' personažej cycle (2008: 131-132, 356); however he also writes that the "theme-images" that formed the cycle's basis emerged and were recorded in 1970, making the earlier date the more likely (137). Šutnik Gorochov is reproduced in full in Kabakov (1994: 50-105). On the political implications of illicit jokes, or anekdoty, see Graham (2009). Kabakov (1994: 52).

Ibid., 53. In fact, this is only a paraphrase of the incident. There is no such pronouncement addressed directly to the sun in Twain's text or in its Russian translation by Kornej Čukovskij. See Twain (1950).

Kabakov (1994: 105).

Graham (2009: 8).

Jackson (2010: 145-150).

Kabakov (1994: 101).

Jackson (2010: 146).

Ibid.

Ibid.

Kabakov (2008: 136-138).

Ibid., 137.

Nabokov (1961: 70); quoted in Boym (1994: 41).

Kabakov (1994: 103).

Boym (1994: 29).

Ibid., 44.

Benjamin (1999: 486-493). Benjamin's book collector, in his nostalgia and romantic relationship to ownership, of course, could be said to exhibit a high degree of pošlost'.

Kabakov (1994: 68-69; 99; 101).

Kabakov (2008: 132).

For historical and social perspectives on the period, see Kotkin (2001); Raleigh (2012). 
$40 \quad$ Kabakov (2008: 132).

$41 \quad$ Kollektivnye dejstvija (1998: 27). For additional documentary photographs as well as descriptive texts and other related material, see <http://conceptualism.letov.ru/KD-actions.html>. Last accessed April 11, 2012.

Kollektivnye dejstvija (1998: 28). For additional photographs see <http://conceptualism.letov.ru/KD-actions-9.html>. Last accessed April 11, 2012.

Ibid., 22.

Ibid., 23.

Ibid., 23-24. Emphasis added.

Jackson (2010: 109).

On Švarcman, Štejnberg, and other unofficial modernists of the 1960s and 1970s, see Alpatova et al. (2005); Degot' (2005: 159-164).

On the utopianisms of the artistic and political avant-gardes, see Buck-Morss (2002: 42-67). For a slightly different reading of the reception of utopianism in the 1970s and 1980s, see Groys (1992: 75-112).

Collective Actions' slogan actions from 1977 and 1978 might be characterized as displaying a muted irony. In 1977, the group hung up a red sheet with the following words emblazoned on it in white lettering: "Я ни на что не жалуюсь и мне все нравится, несмотря на то, что я здесь никогда не был и не знаю ничего об этих местах" ("I do not complain about anything and I like everything, despite the fact that I have never been here before and know nothing about these parts"). In 1978, they hung another sheet, this time blue, with the words: "Странно, зачем я лгал самому себе, что я здесь никогда не был и не знаю ничего об этих местах, - ведь на самом деле здесь так же как везде, только еще острее это чувствуешь и глубже не понимаешь” ("Strange, why did I lie to myself that I have never been here before and know nothing about these parts, when here is just like everywhere else, you just feel it more sharply and more deeply don't understand"). These poetic riffs on the contingency of place, executed first in the form of an official proclamation, but then diverging from this form in the "off" color of blue, are quite different in their relationship to Soviet ideological language from such truly ironic works as Komar and Melamid's white on red slogan pieces Our Goal Is Communism! or Ideal Slogan (both 1972).

Alekseev (2008: 148). For a number of retrospective accounts of the decade from members of the Moscow underground, see Kizeval'ter (2010).

Alekseev (2008: 165). One of the best descriptions of this period can be found in Alekseev's memoir, Rjady pamjati. As a member of both Collective Actions and the New-wave (his apartment housed its short-lived but groundbreaking exhibition space, the Aptart gallery), Alekseev is uniquely able to convey the atmosphere of these years. See also Andrew Solomon's first-hand account of the period, The Irony Tower: Soviet Artists in a Time of Glasnost (1991).

This characterization comes from Rimma and Valery Gerlovin, who introduced the Muchomors to the Moscow Conceptualist circle. See their statement in Alpatova et al. (2005: 266). For information on the Muchomors 
and the New-wave, see individual entries in Alpatova et al. (2005); Alekseev (2008); Solomon (1991); Gundlach (1983: 3-5); V. Tupitsyn (1989: 98-115). See also the recently published volume of primary texts: Muchomor (2010). See Groys's description of the seminar in Groys, Vidokle (2006: 403-404); see also Alekseev (2008: 106-107).

According to accounts, the audience reaction was stunned silence until Kabakov suddenly pronounced the spectacle "genius". See Alekseev (2008: 106-107); Alpatova et al. (2005: 268). For an alternative account of the evening's reception, see Vladimir Mironenko and Konstantin Zvezdočetov's dialogue in Muchomor (2010: 113-115). Alpatova et al. (2005: 270); and Muchomor (2010: 149-153). Alpatova et al. (2005: 271); and Muchomor (2010: 154-155). Solomon (1991: 101-103). Gundlach (1983: 3). The English translation has been slightly modified for accuracy. Alekseev (2008: 160). See also Krečmar (1997: 127-182). Solomon (1991: 109). Alekseev (2008: 168-187). See also Apt Art: Moscow Vanguard in the 80s (1985). Alpatova et al. (2005: 337).

See, for example, the Muchomor action "Ėksperiment! Proekt zaščity ot nejtronnogo oružija!” ("Experiment! Project of Defense against Neutron Weapons"; April 1983), documented in MANI (Moskovskij archiv novogo iskusstva) (1982, 4, envelope 18). See also Alpatova et al. (2005: 321); and many of the poems, drawings, and actions reproduced in the Muchomor volume. Alekseev (2010: 174); Alpatova et al. (2005: 326-327).

See Vadim Zacharov: 25 let na odnoj stranice (2006: 40-41). See also documentation in MANI (1981, 2, June, folder 17).

Boym (1994: 32-40).

Bakhtin (1984: 20).

Bakhtin (1984: 4-23).

Sloterdijk (1987: 103).

One major outlet was the journal A-Ya: Unofficial Russian Art Revue, published in Paris by Igor' Šelkovskij between 1979 and 1987. Reprinted as Šelkovskij (2004).

Ibid., 244.

Ibid., 243.

Huyssen (1987: xviii). 


\section{LITERATURE}

\section{Alekseev, Nikita}

2008 Rjady pamjati. Moskva.

Alpatova, Irina, Ed.

2008 Gnezdo (The Nest): Gennadij Donskoj, Michail Rošal', Viktor Skersis. Moskva.

Alpatova, I., Taločkin, L., Tamruči, N.

2005 'Drugoe iskusstvo': Moskva, 1956-1988. Moskva.

Apt Art: Moscow Vanguard in the '80s

1985 Exh. Cat. Mechanicsville, MD.

Bakhtin, Mikhail

1984 Rabelais and His World. Trans. Hélène Iswolsky. Bloomington.

Balina, Marina, Condee, Nancy, Dobrenko, E.A., Eds.

2000 Endquote: Sots-Art Literature and Soviet Grand Style. Evanston, Ill.

Benjamin, Walter

1999 'Unpacking My Library: A Talk about Collecting'. Walter Benjamin: Selected Writings, Volume 2, Part 2, 1931-1934. Eds. Michael W. Jennings, Howard Eiland, Gary Smith. Cambridge, 486493.

Bobrinskaja, Ekaterina

1994 Konceptualizm. Moskva.

Boym, Svetlana

1994 Common Places: Mythologies of Everyday Life in Russia. Cambridge, London.

Buck-Morss, Susan

2002 Dreamworld and Catastrophe: The Passing of Mass Utopia in East and West. Cambridge, Mass., London.

Degot', Ekaterina 2000 Russkoe iskusstvo XX veka. Moskva.

Degot', Ekaterina, Zacharov, Vadim 2005 Moskovskij konceptualizm. Moskva.

Epstein, Mikhail, Genis, Alexander, Vladiv-Glover, Slobodanka

1999 Russian Postmodernism: New Perspectives on Post-Soviet Culture.

Glezer, Aleksandr New York, Oxford.

1977

Graham, Seth 2009

Groys, Boris

1979

1992
Iskusstvo pod bul'dozerom: sinjaja kniga. London.

Resonant Dissonance: The Russian Joke in Cultural Context. Evanston, Ill.

'Moscow Romantic Conceptualism'. A-Ya, 1, 3-11.

'Postutopian Art: From Myth to Mythology'. The Total Art of Stalinism. Princeton. 
2006 'Moscow Conceptualism Twenty-Five Years Later'. East Art Map: Contemporary Art in Eastern Europe. London, 408-409.

2010 History Becomes Form: Moscow Conceptualism. Cambridge, Mass., London.

Groys, Boris, Hollein, Max, Fontán del Junco, Manuel, Eds.

2008 Total Enlightenment: Conceptual Art in Moscow, 1960-1990. Ostfildern, Germany.

Groys, Boris, Vidokle, Anton

2006 'Art Beyond the Art Market'. East Art Map: Contemporary Art in Eastern Europe. London, 403-404.

Gundlakh, Sven

1983 'Aptart (Pictures from an Exhibition)'. A-Ya, 5, 3-5.

Hoptman, Laura J., Pospiszyl, Tomáš

2002 Primary Documents: A Sourcebook for Eastern and Central Euro-

Huyssen, Andreas pean Art since the 1950s. New York.

1987 'Foreword: The Return of Diogenes as Postmodern Intellectual'. Peter Sloterdijk, Critique of Cynical Reason. Trans. Michael Eldred.

Jackson, Matthew Jesse

Minneapolis, ix-xxv.

2010 The Experimental Group: Ilya Kabakov, Moscow Conceptualism, Soviet Avant-Gardes. Chicago.

Kabakov, Il'ja 2008 60-70e... Zapiski o neoficial'noj žizni v Moskve. Moskva.

Kabakov, Ilya

1994 Five Albums: Installation Operation Room (Mother and Son). Helsinki.

Kizeval'ter, Georgij, Ed.

2010 Eti strannye semidesjatye, ili Poterja nevinnosti: $\dot{E} s s e$, interv'ju, vospominanija. Moskva.

Kollektivnye dejstvija 1998 Poezdki za gorod. Moskva.

Kotkin, Stephen 2001 Armageddon Averted: The Soviet Collapse, 1970-2000. Oxford.

Krečmar [Kretzschmar], Dirk

1997 Politika i kul'tura pri Brežneve, Andropove i Černenko, 1970-1985

Lipovetsky, Mark gg. Trans. M.G. Ratgauz. Moskva.

1999 Russian Postmodernist Fiction: Dialogue with Chaos. Ed. Eliot MANI Borenstein. Armonk.

1981-1986 Moskovskij archiv novogo iskusstva, Vols. 1-5. 
Monastyrskij, Andrej, Panitkov, Nikolaj

2010 'Dialog A. Monastyrskogo i N. Panitkova (o 70-ch godach i akcii “Musorovoz")' (January 7, 2009). Accessed August 28. $<$ http://conceptualism.letov.ru/Andrei-Monastyrski-Panitkov-10dialog.html>.

Muchomor

2010 Sven Gundlach, Konstantin Zvezdočetov, Aleksej Kamenskij, Vladimir Mironenko, Sergej Mironenko. Muchomor. Ed. Alek-

Nabokov, Vladimir sandra Obuchova. Vologda.

1961 Gogol. New York.

Obuchova, Aleksandra, Ed.

2004 Gruppa SZ: Viktor Skersis, Vadim Zacharov, Sovmestnye raboty, 1980-1984. Moskva.

$2010 \quad$ Muchomor. Vologda.

Oxford English Dictionary 2012 3rd Edition. Oxford.

Parvulescu, Anca 2010 Laughter: Notes on a Passion. Cambridge, Mass.

Raleigh, Donald J.

2012 Soviet Baby Boomers: An Oral History of Russia's Cold War Generation. Oxford.

Ratcliff, Carter $1988 \quad$ Komar \& Melamid. New York.

Šelkovskij, I., Ed.

2004 A-Ja. Žurnal neoficial'nogo Russkogo iskusstva. Moskva.

Silaeva, Asja, Ed. 2007 Jurij Al'bert: "Vystavka”. Moskva.

Sloterdijk, Peter 1987 Critique of Cynical Reason. Trans. Michael Eldred. Minneapolis.

Solomon, Andrew 1991 The Irony Tower: Soviet Artists in a Time of Glasnost. New York.

Tamruchi, Natalia 1995 Moscow Conceptualism, 1970-1990. Roseville East, NSW.

Tupitsyn, Margarita 1989 Margins of Soviet Art: Socialist Realism to the Present. Milano.

Tupitsyn, Viktor 2009 The Museological Unconscious: Communal (Post)modernism in Russia. Cambridge, Mass., London.

Twain, Mark 1950 Janki pri dvore korolja Artura. Trans. Nikolaj Korneevič Čukovskij. Moskva.

Vadim Zacharov: 25 let na odnoj stranice $2006 \quad$ Exh. Cat. Moskva. 
Vasmer's Etymological Dictionary

1998

Online edition.

Yurchak, Alexei

2006

Everything Was Forever, Until It Was No More: The Last Soviet Generation. Princeton, Oxford. 